\title{
Isolasi dan Identifikasi Bakteri Resisten Arsen pada Sedimen di Pesisir Laut Buyat Tahun 2018
}

\author{
${ }^{1}$ Natalia M. Pantow \\ ${ }^{2}$ Billy J. Kepel \\ ${ }^{2}$ Fatimawali
}

\author{
${ }^{1}$ Program Studi Pendidikan Dokter Fakultas Kedokteran Universitas Sam Ratulangi Manado \\ ${ }^{2}$ Bagian Kimia Fakultas Kedokteran Universitas Sam Ratulangi Manado \\ Email: nataliapantow@yahoo.com
}

\begin{abstract}
Metals are very important and widely used in many aspects of human life, however, they can cause environmental pollution which is harmful to life. Arsenic is a very toxic metal that can cause kidney damage and is responsible to various chronic health problems, especially cancer. The coastal area of Buyat Sea in North Sulawesi Province has a high level of activity in mining industry. The mining waste results in environmental pollution due to arsenic release, thus triggers the occurence of arsenic-resistant bacteria. This study was aimed to determine whether there were arsenic-resistant bacteria in soil sediment originated from the coastal area of Buyat Sea and to identify the types of arsenic-resistant bacteria. This was a descriptive explorative study. Samples of soil sediment were obtained from one point on the coastal area of Buyat Sea. The results showed that there were 10 isolates of arsenic-resistant bacteria. There were five genera of bacteria that were resistant to arsenic, namely Escherichia, Klebsiella, Hafnia, Staphylococcus, and Bacillus. Conclusion: In the coastal area of Buyat Sea, five genera of arsenic-resistant bacteria were identified, as follows: Escherichia, Klebsiella, Hafnia, Staphylococcus, and Bacillus.
\end{abstract}

Keywords: arsenic, sediment, arsenic-resistant bacteria

\begin{abstract}
Abstrak: Logam sangat penting dalam berbagai aspek kehidupan manusia walaupun dapat mencemari lingkungan dan berbahaya bagi kehidupan. Arsen merupakan logam berat yang sangat bersifat toksik dan dapat merusak ginjal serta bertanggung jawab terhadap berbagai gangguan kesehatan kronis, termasuk kanker. Daerah pesisir Buyat laut di Provinsi Sulawesi Utara memiliki tingkat aktivitas yang tinggi dalam bidang industri pertambangan. Limbah pertambangan mengakibatkan terjadinya pencemaran lingkungan oleh karena pelepasan arsen yang dapat memicu terjadinya bakteri resisten arsen. Penelitian ini bertujuan untuk mengetahui apakah terdapat bakteri resisten arsen pada sedimen yang berasal dari daerah pesisir laut Buyat dan untuk mengidentifikasi jenis bakteri resisten arsen yang ditemukan. Jenis penelitian ialah deskriptif eksploratif. Sampel penelitian ialah sedimen tanah di satu titik di pesisir laut Buyat. Hasil penelitian mendapatkan 9 isolat bakteri resisten arsen dan ditemukan lima genus bakteri yang resisten terhadap arsen yaitu Escherichia, Klebsiella, Hafnia, Staphylococcus, dan Bacillus. Simpulan: Di daerah pesisir laut Buyat ditemukan bakteri resisten arsen pada sedimen yaitu genus Escherichia, Klebsiella, Hafnia, Staphylococcus, dan Bacillus.
\end{abstract}

Kata kunci: arsen, sedimen tanah, bakteri

Logam sangat penting dan banyak dipakai dalam aspek kehidupan manusia. Beberapa logam berat banyak digunakan dalam berbagai keperluan sehari-hari dan secara langsung maupun tidak langsung dapat mencemari lingkungan dan apabila sudah 
melebihi batas yang ditentukan berbahaya bagi kehidupan. ${ }^{1}$ Arsen merupakan logam berat berbentuk serbuk atau pelet, berwarna abu-abu metalik, tidak berbau, tidak larut dalam air. Arsen dijumpai di tanah, air, dan udara. Unsur arsen ditemukan sebagai hasil sampingan dari peleburan tembaga, timah, seng, dan logam lainnya. Pembakaran fosil terutama batu bara, mengeluarkan $\mathrm{As}_{2} \mathrm{O}_{3}$ ke lingkungan, dimana sebagian besar akan masuk ke dalam perairan alami. Arsen dalam air tanah terbagi dalam dua bentuk, yaitu bentuk tereduksi terbentuk dalam kondisi anaerobik dalam bentuk $\mathrm{As}^{3-}$ sering disebut arsenit. Bentuk lainnya ialah bentuk teroksidasi, terjadi pada kondisi aerobik dalam bentuk $\mathrm{As}^{3+}$ disebut sebagai arsenat. Arsen merupakan logam berat yang bersifat sangat toksik yang dapat merusak ginjal, dan bertanggung jawab terhadap berbagai gangguan kesehatan kronis, terutama kanker. ${ }^{2-4}$

Daerah pesisir Buyat laut di Provinsi Sulawesi Utara merupakan daerah perairan yang memiliki tingkat aktivitas manusia yang cukup tinggi, terutama dalam bidang industri yaitu pertambangan. Hal ini memungkinkankan arsen dapat masuk ke perairan laut, yang pada akhirnya akan masuk ke rantai makanan di laut sehingga membahayakan kesehatan manusia. ${ }^{5}$

Salah satu usaha untuk detoksifikasi arsen dapat dilakukan dengan menggunakan mikroorganisme resisten arsen, misalnya bakteri resisten arsen. Detoksifikasi oleh bakteri resisten arsen terjadi karena bakteri tersebut memiliki gen resisten arsen.

Ketika koloni bakteri menetap pada kondisi yang menekan seperti konsentrasi arsen yang tinggi dalam waktu lama, maka dapat menyebabkan koloni bakteri tersebut mengembangkan mekanisme untuk mendetoksifikasi dan mengatasi pembatasan untuk bertumbuh sehingga walaupun pada konsentrasi tinggi arsen, masih terdapat bakteri yang tumbuh.

\section{METODE PENELITIAN}

Penelitian ini menggunakan metode deskriptif eksploratif. Pengambilan sampel dilakukan di Teluk Buyat. Analisis lanjut untuk isolasi dan identifikasi bakteri dilakukan di Laboratorium Farmasi Fakultas Matematika dan Ilmu Pengetahuan Alam (FMIPA) Universitas Sam Ratulangi sejak bulan September sampai November 2018.

Sampel penelitian yang digunakan ialah koloni bakteri resisten terhadap arsen yang diisolasi dari sedimen tanah di Laut Buyat. Sedimen tanah di daerah Laut Buyat diambil pada jam 10.00-12.00 yang merupakan waktu air laut tersurut. Sedimen tersebut dimasukkan ke dalam botol steril. Untuk menjaga kondisi sedimen maka disimpan dalam cool box selama perjalanan.

Sebanyak 1 gr sampel sedimen dilarutkan dalam $10 \mathrm{~mL} \mathrm{NaCl}$, lalu disentrifugasi selama 10 menit. Larutan arsenit dibuat dengan melarutkan $100 \mathrm{mg} \mathrm{As}_{2} \mathrm{O}_{3}$ ke 100 $\mathrm{mL}$ akuades hangat dengan suhu $50^{\circ} \mathrm{C}$. Media pertumbuhan Luria Bertani (LB) agar dibuat dengan mencampurkan $\mathrm{NaCl}$ $1 \%$, tripton $1 \%$, agar $1.5 \%$, yeast extract $0.5 \%$ yang dilarutkan dalam $1000 \mathrm{~mL}$ akuades. Media LB dicampurkan dengan $\mathrm{As}_{2} \mathrm{O}_{3}$ dengan konsentrasi 5 ppm, $10 \mathrm{ppm}$, 20 ppm, 40 ppm, 80 ppm, 100 ppm, 300 ppm, 500 ppm, 1000 ppm.

Sampel sedimen yang sudah disiapkan dimasukkan kedalam media LB yang sudah dibuat, kemudian diinkubasi selama 24 jam pada suhu $37^{\circ} \mathrm{C}$. Setelah bakteri tumbuh, koloni bakteri selanjutnya dimurnikan pada media LB agar yang sudah mengandung $\mathrm{As}_{2} \mathrm{O}_{3}$ dengan konsentrasi yang sudah ditentukan, lalu dilakukan metode streak plate, yaitu dengan menggoreskan jarum Ose yang terdapat bakteri ke media LB agar.

Uji morfologi dengan pewarnaan Gram, uji fisiologi berupa motilitas di nutrient agar, dan uji biokimia menggunakan indol, $\mathrm{H}_{2} \mathrm{~S}$, fermentasi karbohidrat, katalase, sitrat, dan lisin. Hasil uji tersebut dicocokkan dengan Bergey's Manual of Systematic Bacteriology, untuk menentukan genus.

\section{HASIL PENELITIAN}

Pada proses pemilihan isolasi bakteri, 
dipilih koloni berdasarkan bentuk dan luas permukaan yang tampak pada media LB. Setelah diberi tanda, koloni tersebut digoreskan pada media LB padat di cawan Petri secara terpisah satu sama lain kemudian diberi label BL 5 ppm, BL 10 ppm, BL 20 ppm, BL 40 ppm, BL 80 ppm, BL 100 ppm, BL 300 ppm, BL 500 ppm, dan BL 1000 ppm. Yang tidak mengandung arsen diberi kode Kontrol I. Setiap sampel di tingkat ppm yang berbeda-beda. Koloni bakteri tumbuh dengan warna putih keruh. Koloni yang terbentuk pada media LB padat tersebut diinokulasikan pada media agar miring masing-masing. Isolat yang terbentuk pada media agar miring selanjutnya diidentifikasi melalui uji fisiologi, uji morfologi, dan uji biokimia.

\section{Hasil Identifikasi Bakteri}

Hasil pengujian 10 isolat pada media tes motilitas mendapatkan 9 isolat yang menunjukkan hasil negatif yaitu bakteri tidak menunjukkan adanya pertumbuhan menyebar, dan 1 isolat yang menunjukkan hasil positif yaitu isolat yang tidak mengandung arsen. Hal ini menunjukkan adanya pertumbuhan bakteri yang menyebar pada isolat tersebut.

Hasil yang didapatkan pada uji morfologi dalam bentuk pewarnaan Gram. Isolat dengan kode BL 20 ppm ialah bakteri bentuk kokus Gram positif; isolat BL 5 ppm dan BL 40 ppm ialah bakteri kokobasil Gram negatif; isolat BL 100 ppm, BL 300 ppm, BL 500 ppm, dan BL 1000 ppm ialah bakteri bentuk basil Gram positif; sedangkan isolat dengan kode BL kontrol I, BL 10 ppm, dan BL 80 ppm merupakan bakteri bentuk basil Gram negatif.

Uji fermentasi karbohidrat dilakukan pada media TSIA (Triple Sugar Iron) agar. Isolat dengan kode BL 40 ppm tidak memperlihatkan perubahan warna, sehingga media tetap berwarna merah. Hal ini menunjukkan bahwa tidak terjadi fermentasi karbohidrat apapun pada isolat. Isolat dengan kode BL kontrol I, BL 5 ppm, BL 10 ppm, BL 20 ppm, BL 80 ppm, BL 100 ppm, BL 300 ppm, dan BL 1000 ppm, memiliki perubahan menjadi warna kuning pada bagian dasar (butt), dan tetap berwarna merah pada bagian permukaan (slant) disertai pembentukan gas (CO2). Hal ini berarti bahwa pada sampel hanya terjadi fermentasi glukosa saja tanpa disertai fermentasi laktosa atau sukrosa, dan disertai dengan pembentukan gas (CO2). Pada isolat dengan kode BL 500 ppm terjadi perubahan warna media, dari merah menjadi kuning sepenuhnya disertai adanya pembentukan gas pada tabung. Hal ini menunjukkan adanya fermentasi karbohidrat secara keseluruhan disertai munculnya gas $(\mathrm{CO} 2)$.

Uji $\mathrm{H}_{2} \mathrm{~S}$ menggunakan media TSI dan semua isolat menunjukkan hasil yang negatif karena tidak terlihat adanya endapan warna hitam pada tabung, yang berarti bakteri tidak membentuk $\mathrm{H} 2 \mathrm{~S}$.

Uji indol menggunakan media nutrient agar yang diberi 5 tetes reagen Kovac's, kemudian didiamkan sebentar. Pada uji indol tidak didapatkan hasil positif, yaitu tidak terbentuknya cincin berwarna merah di permukaan media, yang artinya bakteri tidak mengandung enzim triptofanase yang merupakan katalis pengurai gugus indol yang terkandung dalam asam amino triptofan.

Pada penelitian ini uji sitrat dilakukan dengan menggunakan media Simmon's Citrate Agar. Hampir semua isolat memberikan hasil positif dimana terjadi perubahan warna media dari hijau menjadi biru. Hasil negatif didapatkan pada isolat dengan kode BL kontrol I dimana tidak terjadi perubahan warna pada media.

Uji lisin menggunakan media Lisin Iron Agar. Isolat dengan kode BL 40 ppm memberikan hasil positif berupa adanya gumpalan berwarna lembayung (keunguan). Hal ini menunjukkan bahwa bakteri dapat melakukan dekarboksilasi dalam asam amino berupa lisin melalui produksi enzim dekarboksilase. Hasil negatif didapatkan pada isolat dengan kode BL control I, BL 5 ppm, BL 10 ppm, BL 20 ppm, BL 80 ppm, BL 100 ppm, BL 300 ppm, BL 500 ppm, dan BL 1000 ppm, dimana tidak terdapat gumpalan berwarna lembayung (keunguan), tetapi terjadi perubahan warna 
ke warna kuning.

Uji katalase menggunakan media nutrient agar yang ditetesi dengan larutan larutan peroksida $\left(\mathrm{H}_{2} \mathrm{O}_{2}\right)$.. Hasil positif ditunjukkan dengan munculnya busa/gas yang merambat cepat keluar dari tabung.
Semua isolat menunjukkan hasil positif. Hal ini menunjukkan bahwa bakteri pada isolate memiliki enzim katalase yang dapat memecah $\mathrm{H}_{2} \mathrm{O}_{2}$ menjadi $\mathrm{H}_{2} \mathrm{O}$ dan $\mathrm{O}_{2}$.

Hasil uji secara keseluruhan dirangkum dalam tabel 1.

Tabel 1. Hasil uji isolat bakteri resisten arsen dengan metode identifikasi bakteri konvensional

\begin{tabular}{|c|c|c|c|c|c|c|c|c|c|c|}
\hline \multirow{2}{*}{$\begin{array}{c}\text { Uji } \\
\text { Identifikasi }\end{array}$} & \multicolumn{10}{|c|}{ Isolat bakteri resistensi arsen } \\
\hline & $\begin{array}{c}\mathrm{BL} \\
\text { kontrol }\end{array}$ & $\begin{array}{c}\mathrm{BL} \\
5\end{array}$ & BL 10 & $\begin{array}{l}\text { BL } \\
20\end{array}$ & $\begin{array}{c}\mathrm{BL} \\
40\end{array}$ & $\begin{array}{l}\mathrm{BL} \\
80\end{array}$ & $\begin{array}{l}\mathrm{BL} \\
100\end{array}$ & $\begin{array}{l}\mathrm{BL} \\
300\end{array}$ & $\begin{array}{l}\mathrm{BL} \\
500\end{array}$ & $\begin{array}{c}\text { BL } \\
1000\end{array}$ \\
\hline Morfologi & $(-) B$ & $(-) \mathrm{K}$ & (-) B & $(+) \mathrm{K}$ & $(-) \mathrm{B}$ & (-) B & (+) B & $(+) \mathrm{B}$ & (+) B & (+) B \\
\hline F. karbohidrat & g,gas & g,gas & g,gas & g,gas & - & g,gas & g,gas & g,gas & $\mathrm{g}, \mathrm{f}, 1, \mathrm{gas}$ & g,gas \\
\hline Motil & + & - & - & - & - & - & - & - & - & - \\
\hline Indol & - & - & - & - & - & - & - & - & - & - \\
\hline Sitrat & - & + & + & + & + & + & + & + & + & + \\
\hline Lysin & - & - & - & - & + & - & - & - & - & - \\
\hline $\mathrm{H}_{2} \mathrm{~S}$ & - & & - & - & - & - & - & - & - & - \\
\hline Katalase & + & + & + & + & + & + & + & + & + & + \\
\hline
\end{tabular}

B: Basil; K: Kokus; g: glukosa; f: fruktosa; l: laktosa; gas: ada produksi gas dari hasil fermentasi karbohidrat.

Tabel 2. Genus bakteri resisten arsen

\begin{tabular}{cc}
\hline Kode isolat & Genus \\
\hline BL kontrol I & Eschericia \\
BL 5 ppm & Klebsiella \\
BL $10 \mathrm{ppm}$ & Hafnia \\
BL $20 \mathrm{ppm}$ & Staphylococcus \\
BL $40 \mathrm{ppm}$ & Klebsiella \\
BL $80 \mathrm{ppm}$ & Hafnia \\
BL $100 \mathrm{ppm}$ & Bacillus \\
BL $300 \mathrm{ppm}$ & Bacillus \\
BL $500 \mathrm{ppm}$ & Bacillus \\
BL $1000 \mathrm{ppm}$ & Bacillus \\
\hline
\end{tabular}

\section{BAHASAN}

Bakteri umumnya berbentuk satu sel atau sel tunggal (unisel), tidak mempunyai klorofil, dan berkembangbiak dengan pembelahan sel atau biner. Istilah bakteri berasal dari kata bakterion (bahasa Yunani) yang berarti tongkat atau batang. Karena tidak mempunyai klorofil maka bakteri hidup sebagai jasad yang saprofitik ataupun parasitik. Tempat hidupnya tersebar dimana-mana, yaitu di udara, di dalam tanah, di dalam air, pada bahan-bahan, pada tanam- an, tubuh manusia, atau hewan. ${ }^{6}$

Pada penelitian yang dilakukan terhadap sedimen tanah di pesisir Buyat Laut ditemukan bakteri resisten arsen melalui uji resistensi arsen. Semua isolat diambil dari sampel tumbuh pada pemberian $\mathrm{As}_{2} \mathrm{O}_{3}$ dengan konsentrasi 5 ppm, 10 ppm, 20 ppm, 40 ppm, 80 ppm, 100 ppm, 300 ppm, 500 ppm, dan 1000 ppm, kemudian diinkubasi pada suhu $37^{\circ} \mathrm{C}$ selama 18-24 jam.

Kemampuan bakteri untuk mereduksi atau mengoksidasi ion-ion logam sangat 
bervariasi tergantung dari genus bakteri. Escherichia merupakan bakteri berbentuk basil pendek Gram negatif yang dapat bersifat motil maupun non motil. Uji fermentasi karbohidrat menunjukkan adanya pembentukan asam dan gas, tetapi ada juga yang tidak. Ditemukan pada feses, namun kadang-kadang dapat bersifat patologik. Salah satu genus Escerichia yang dapat menimbulkan penyakit ialah $E$. coli yang menghasilkan enterotoksin dan menyebabkan beberapa kasus diare. E. coli berasosiasi dengan enteropatogenik menghasilkan enterotoksin pada sel epitel. Penyakit yang disebabkan oleh $E$. coli yaitu infeksi saluran kemih, diare, sepsis, dan meningitis. ${ }^{7}$

Klebsiella merupakan bakteri Gram negatif berbentuk basil pendek, cenderung lebih bulat dengan ujung yang membulat dan kebanyakan ditemukan terpisah-pisah. Bakteri ini non motil. Uji fermentasi karbohidrat dapat menghasilkan hasil bervariasi, tetapi biasanya karbohidrat terfermentasi. Bakteri ini hidup dalam keadaan aerobik. Dalam tubuh, bekteri ini dapat ditemukan pada saluran napas, cerna, dan kemih. ${ }^{7,8}$

Hafnia adalah genus bakteri berbentuk basil Gram negatif anaerob, dapat motil pada suhu $22^{\circ} \mathrm{C}$ dan non motil pada $38^{\circ} \mathrm{C}$. Genus ini hanya memiliki satu spesies heterogen, yaitu Hafnia alvei. Bakteri ini dapat ditemukan pada feses manusia sehat. Selain itu, bakteri ini dapat ditemukan pada saluran cerna manusia, dan dalam keadaan patologik dapat ditemukan pada gastroenteritis. $^{7-9}$

Staphylococcus merupakan sel bulat kokus Gram positif yang bergerombol seperti anggur. Uji katalase menunjukkan hasil positif, non motil. Organisme ini dapat tumbuh dalam banyak jenis medium dan aktif secara metabolik. Beberapa bakteri memroduksi pigmen berwarna jingga atau kuning, biasanya pada media yang mengandung banyak $\mathrm{NaCl}$. Dapat ditemukan di kulit, nasal, dan membran mukosa lainnya. Pada kulit, dapat menyebabkan supurasi, dan pembentukan abses. Staphylococcus dapat menjadi resisten dengan cepat terhadap agen-agen anti- mikroba yang mengakibatkan kesulitan pemberian terapi. ${ }^{7,8}$

Bacillus merupakan genus bakteri basil Gram positif aerob, yang muncul dalam bentuk rantai. Sebagian besar anggota dari genus ini ialah organisme saprofit, sering dijumpai pada tanah, air dan udara, dan pada vegetasi. Bakteri pada genus ini juga tumbuh dalam makanan dan menghasilkan enterotoksin atau toksin emetik yang menimbulkan sindrom muntah 1-6 jam setelah makan. Organisme ini juga kadangkadang dapat menimbulkan penyakit seperti endokarditis, meningitis, endoftalmitis, konjungtivitis, dan gastroenteritis akut. $+7,8$

\section{SIMPULAN}

Berdasarkan hasil penelitian, ini dapat disimpulkan bahwa terdapat lima genus bakteri resisten arsen pada sedimen tanah di pesisir Buyat Laut yaitu Escherichia, Klebsiella, Hafnia, Staphylococcus, dan Bacillus yang diidentifikasi dengan uji morfologi, uji fisiologi, dan uji biokimia.

\section{SARAN}

Disarankan kepada masyarakat di daerah Buyat untuk lebih berhati-hati dalam pengolahan limbah tambang industri agar tidak mencemari lingkungan. Untuk mendapatkan hasil identifikasi jenis bakteri yang lebih tepat perlu dilakukan identifikasi biomolekuler atau dengan melakukan uji biokimia lainnya.

Ucapan terima kasih ditujukan kepada Ibu Nurmiati, S.Si dan semua pihak yang baik secara langsung atau tidak langsung telah menumbuhkan ide dan gagasan dalam penulisan artikel ini.

\section{DAFTAR PUSTAKA}

1. Luthfillah. Kasus Newmont (Pencemaran di Teluk Buyat). Jurnal Kybernan. 2011; 2(1):1-29.

2. Kholishotunnisa S. Logam berat sekitar manusia. Banjarmasin: Lambung Mangkurat University Press, 2017; p. 57-8.

3. Endrinaldi. Logam-logam berat pencemaran lingkungan dan efek terhadap manusia 
Jurnal Kesehatan Masyarakat. 20092009;4(1):42-6.

4. Festri I. Studi dampak arsen (As) dan Kadmiun (Cd) terhadap Penurunan Kualitas Lingkungan. Jurnal Teknik Pomits. 2014;3(1):D53-D58.

5. Rumampuk NDC, Warouw V. Bioakumulasi total merkuri, arsen, kromium, cad-mium, timbal di Teluk Totok dan Teluk Buyat, Sulawesi Utara. Jurnal LPPM Bidang Sains dan Teknologi. 2015; 2(2):49-59.

6. Cotton FA, Wilkinson G. Kimia Anorganik Dasar. Jakarta: UI-Press, 2009.

7. Thomas DJ, Styblo M, Lin S. The cellular metabolism and systemic toxicity of arsenic. Toxicol Appl Pharmacol. 2001; 176:127-44.

8. Meganada HP, Sukini, Yodong. Mikrobiologi (1st ed). Jakarta: Kementerian
Kesehatan RI BPPSDMK, 2017; p. 1129

9. Cowan MK. Microbiology: A Systems Approach (3rd ed). Miami: McGraw Hill, 2012.

10. John GH, Noel RK, Peter HAS, Staley J, Williams S. Bergey's Manual of determinative bacteriology (9th ed). Baltimore: The Williams \& Wilkins Company, 1994.

11. Brooks GF, Carroll KC, Butel JS, Morse SA, Mietzner TA. Jawetz, Melnick, \& Adelberg's Medical Microbiology. In: Adityaputri A, editor. Jawetz, Melnick, \& Adelberg Mikrobiologi Kedokteran (25th ed). Jakarta: EGC, 2010.

12. McBee ME, Schauer DB. The genus Hafnia. The Prokaryotes. New York: Springer, 2006; p. 215. 